\title{
Epicatechin Enhances Anti-Proliferative Effect of Bleomycin in Ovarian Cancer Cell
}

\author{
Seyed Jalal Hosseinimehr ${ }^{1 *}$, Mostafa Rostamnezad ${ }^{1}$, Vahid Ghafari-rad ${ }^{1}$ \\ ${ }^{1}$ Department of Radiopharmacy, Faculty of Pharmacy, Pharmaceutical Research Center, Mazandaran University of Medical Sciences, Sari, Iran.
}

Received: 15 Sep 2013

Revised : 20 Oct 2013

Accepted: 15 Nov 2013

Corresponding Authors:

Seyed Jalal Hosseinimehr

Department of Radiopharmacy,

Faculty of Pharmacy, Pharmaceutical

Research Center, Mazandaran

University of Medical Sciences, Sari,

Iran.

Phone: +989113210663

E-mail: sjhosseinim@yahoo.com

\begin{abstract}
Background: Bleomycin (BLM) is an anti-cancer drug widely used in the treatment of cancer. BLM causes several side effects related to DNA and cellular damage. The aim of this study was investigated the effects of tea polyphenol epicatechin on anti-proliferative effects induced by bleomycin in human normal skin and human ovarian cancer cells.
\end{abstract}

Materials and Methods: Human ovarian cancer cell (SKOV-3) and human nonmalignant fibroblast cell (HFFF2) were treated with epicatechin at various concentrations $(10,25$ and $50 \mu \mathrm{M})$ and BLM alone and with their combinations, further their effects on cell viability were evaluated.

Results: The combined treatment of epicatechin with BLM enhanced significantly inhibition of cell growth in comparison to BLM alone in cancer cell. Epicatechin enhanced significantly cytotoxicity induced by BLM with $83 \%$ at dose $50 \mu \mathrm{M}$, while it was $92 \%$ in BLM-treated cells. Epicatechin was not showed any cytotoxicity on HFFF2 cells.

Conclusion: Study suggests that epicatechin chemosensitize the ovarian cancer cell to BLM-induced growth inhibition without any toxicity on normal cell.

Keywords:Bleomycin;Epicatechin;Tea;Anti-proliferation;MTT;Ovarian cancer

Please cite this article as: Hosseinimehr SJ, Rostamnezad M, Ghafari-rad V. Epicatechin Enhances Anti-Proliferative Effect of Bleomycin in Ovarian Cancer Cell. Res Mol Med. 2013; 1 (3): 25-28.

\section{Introduction}

Bleomycin is a family of glycopeptide antibiotics which uses widely for treatment of different cancers. BLM binds to DNA (not RNA) through its aminoterminal peptide, and generates free radicals that attack to DNA and producing single and double strand breaks (1). DNA damage by BLM depends on metal ions and oxygen. BLM is forming a complex with metal mainly iron (Fe (II)), this complex with a one-electron reductant activates BLM. Activated BLM produces superoxide and hydroxide free radicals that cleave DNA $(2,3)$. BLM acts as cell arrest in the $G_{2}-M$ phase of the cell cycle (4). BLM causes extensive damage to DNA similar to that generated by ionizing radiation; BLM is known as a radiomimetic drug (5). Therefore BLM causes DNA cleavage and fragmentation leading finally to cellular apoptosis, necrosis and deaths. However, the antineoplastic drug bleomycin is now a second-line therapy for certain solid tumors (6), it causes several side effects such as nausea, vomiting, fever (often with rigors) and occasional allergic type reactions, but pulmonary toxicity are is a major adverse effect (7). This side effect was widely studied in animal models and it is related to oxidant-induced inflammatory and fibrotic lesions in the lung through oxidative stress $(5,8)$.

Green tea polyphenols are potent antioxidants (9). Green tea is containing flavan-3-ols, commonly knownascatechins, whichinclude(-)-epigallocatechin3-gallat (EGCG), (-)-epigallocatechin (EGC), (-)epicatechin-3-gallate (ECG) and (-)-epicatechin(EC) (10).

However, several experiments demonstrated the inhibitory action of tea components against carcinogenesis in animal models such as lung, skin, breast and stomach cancers (11-14). 
<smiles>Oc1cc(O)c2c(c1)O[C@H](c1ccc(O)c(O)c1)[C@H](O)C2</smiles>

Figure 1. Chemical structure of epicatechin

The antitumor effects of these green tea catechins have been studied at cellular level, and the catechins were found to be induced apoptosis and cell cycle arrest. Potential mechanisms have also been suggested to include anti-oxidative activity, inhibition of enzymes related to tumor promotion such as cyclooxygenase and lipoxy- genase, inhibition of activator protein-1, inhibition of angiogenesis, activation of p53 tumor suppressor protein and inhibition of telomerase and metalloproteinases activity (11-17).

The present study was investigated the effects of tea polyphenol epicatechin on anti-proliferative effects induced by bleomycin in human non-malignant fibroblast cell and human ovarian cancer cells.

\section{Materials and Methods \\ Chemicals}

Epicatechin (Fluka, USA) and Bleomycin (Kwality, India) were dissolved in sterile water at stock solution and diluted with RPMI 1640 medium. 3-[4, 5dimethylthiazol-2-yl]-2, 5-diphenyl tetrazoliumbromide (MTT) was purchased from Sigma (USA).

\section{Cell culture}

Human ovarian cancer (SKOV-3) and human skin fibroblast (HFFF2) cells were got from the Pasture Institute of Iran and cultured at $37{ }^{\circ} \mathrm{C}$ and $5 \% \mathrm{CO}_{2}$ in Roswell Park Memorial Institute (RPMI) 1640 medium (Gibco, Paisley, UK) supplemented with $10 \%$ fetal bovine serum (FBS) and $100 \mu \mathrm{g} / \mathrm{ml}$ penicillinstreptomycin (Gibco). Experiments on cells were performed in the exponential growth phase.

\section{Cell anti-proliferation assay}

Untreated and treated SKOV-3 and HFFF2 cells were subjected to cell proliferation assay using MTT to quantify the metabolic activity to cleave tetrazolium salts $(18,19)$. Cells $(20,000)$ were seeded in 96-well plates. After $24 \mathrm{~h}$ incubation, cells were treated with various concentrations of epicatechin $(10,25$ and 50 $\mu \mathrm{M})$ and incubated for $2 \mathrm{~h}$ at $37{ }^{\circ} \mathrm{C}$ and $5 \% \mathrm{CO}_{2}$. Also, RPMI 1640 culture medium was set as negative control, and only culture medium without any cells was set as blank control. After incubation, BLM was added at $10 \mu \mathrm{g} / \mathrm{mL}$ to each well. All testing and control groups were repeated in triplicate. At 48 hours of culture, $20 \mu \mathrm{L}$ MTT $(5 \mathrm{mg} / \mathrm{mL}$ in phosphate buffer saline) was added to every well, and culturing was continued for 4 hours. Then, culture supernatant was discarded and replaced by $150 \mu \mathrm{L}$ isopropanol $(0.1 \% \mathrm{HCl})$, and the cell plates were shaken for 30 minutes. Finally, the absorbance of every culture well was read on an ELISA Reader (Bioteck, USA) at $490 / 630 \mathrm{~nm}$.

\section{Statistical analysis}

Data were presented as mean \pm standard deviation (SD) of three independent experiments. Data were compared and the differences were considered significant if the $p$ value $<0.05$.

\section{Results}

Cell viability of SKOV-3 and HFFF2 cells treated with the doses of epicatechin in combination with BLM or alone was determined by MTT colorimetric assay. To examine the effect of epicatechin on ovarian cancer, SKOV-3 cells were treated with various concentrations $(10,25$ and $50 \mu \mathrm{M})$ of epicatechin for $48 \mathrm{~h}$. Epicatechin alone was not showed any inhibitory effects on SKOV-3 cells. BLM alone was not showed any significantly inhibition effect on growth of SKOV-3 cells, however, epicatechin in combination with BLM was exhibited a dose-dependent manner in growth inhibitory on ovarian cancer cells (Figure 2).

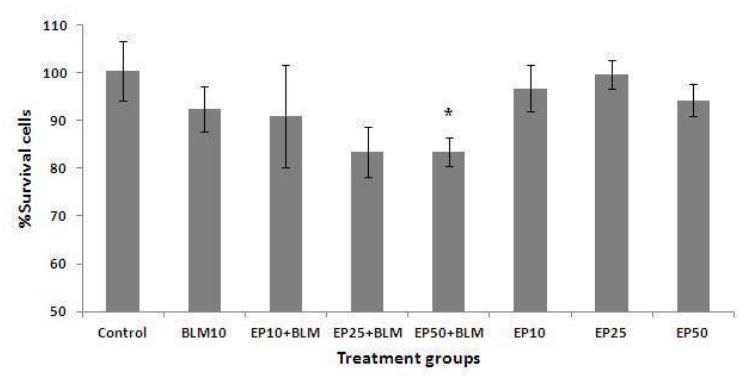

Figure 2. Anti-proliferative effects of epicatechin (EP) (10, 25 and $50 \mu \mathrm{M})$ with bleomycine (BLM) $(10 \mu \mathrm{g} / \mathrm{mL})$ on ovarian cancer cell (SKOV-3).

*p value $<0.01$ compared to control

Epicatechin enhanced significantly cytotoxicity with $83 \%$ at dose $50 \mu \mathrm{M} \quad(\mathrm{p}<0.01)$. Other doses of epicatechin $(10$ and $25 \mu \mathrm{M})$ were not significantly exhibited any enhancement cytotoxicity in combination with BLM. HFFF2 cell was selected as a normal human skin fibroblast for assessment of any cytotoxicity induced by BLM in combination with epicatechin. Anti-proliferation on HFFF2 cells was not observed at various concentrations of epicatechin 
alone. Epicatechin was not showed any significantly enhancement cytotoxicity in combination with BLM on HFFF2 (Figure 3).

\section{Discussion}

The recent preclinical success of epicatechin tea polyphenol in growth suppression of cancer cells suggested the potential uses of dietary substances in the treatment of cancers in combination of bleomycin as a well known anticancer agent. It is may interested to research by combining phytochemicals with chemotherapy, it is possible to improve the effectiveness of the cancer treatment and minimizing toxicity (20).

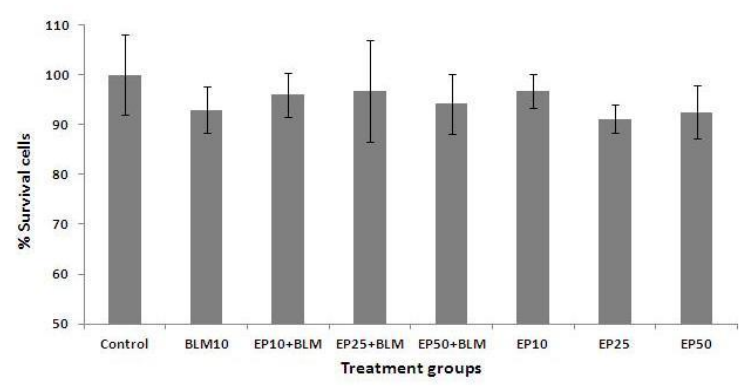

Figure 3. Anti-proliferative effects of epicatechin (EP) (10, 25 and $50 \mu \mathrm{M})$ with bleomycine (BLM) $(10 \mu \mathrm{g} / \mathrm{mL})$ on human normal skin cell (HFFF2).

Non significant was observed between groups

We compared these effects with the cytotoxic chemotherapeutic agent BLM, alone or in combination with epicatechin for development of less toxic treatment strategies for ovarian cancer cell. Epicatechin acted as anti-carcinogenic effects against oxidative stress and protected promotion phase of cancer in liver epithelial cell (21). Several studies showed that epicatechin exhibited anti-tumor affects (22-24). It is clear that anti-cancer agent such as BLM is producing oxidative stress leading to cellular toxicity, and then epicatechin may have a contraindication with BLM on cancer cells. Our finding showed that epicatechin exhibited enhancement toxicity in combination with BLM on ovarian cancer cell, while it was not showed any cytotoxicity on normal human skin cell. These results are interesting for usage of this tea component in cancer chemo- therapy. There are proposed two mode actions for epicatechin, first it acts as anticancer on tumor cells, and secondly epicatechin enhances the efficacy of BLM on inductions of growth inhibition in human ovarian cancer cell. Epicatechin acted inhibiting the binding of NF- $\mathrm{\kappa B}$ to DNA and inhibited cellular growth on Hodgkin's lymphoma, this inhibition was not associated with epicatechin antioxidant activity (25). Epicatechin was found to have cytotoxic activity, and cells treated with this compound had fragmented nuclei, fragmented
DNA, and underwent apoptosis on SW480 human colon cancer (26). Saha et al. reported that the combination of curcumin with epicatechin significantly increased the inhibition of cell growth compared with curcumin or epicatechin alone. Epicatechin may enhance the incorporation of curcumin into human lung cancer cell lines PC-9 and A549 (27). It is hypothesized that two above mentioned actions participated a chemosensitive effect of epicatechin on cytotoxicity induced by BLM.

\section{Conclusion}

The present study shows that epicatechin, a naturally occurring tea polyphenolic agent, could enhance the anti-proliferation of bleomycin on human ovarian cancer cells SKOV-3. It was also shown that epicatechin did not caused any inhibition on normal human skin cells HFFF2. As evidenced from the results, epicatechin may be a powerful candidate in the development of therapeutic agents for ovarian cancer therapy with bleomycin. On the basis of these results, further investigations and in vivo must be performed to determine the possible clinical applications of these combinations.

\section{References}

1. Sikic BI. Biochemical and cellular determinants of bleomycin cytotoxicity. Cancer Surv. 1986; 5 (1): 81-91. PMID: 2439200

2. Chen J, Ghorai MK, Kenney G, Stubbe J. Mechanistic studies on bleomycin-mediated DNA damage: multiple binding modes can result in double-stranded DNA cleavage. Nucleic Acids Res. 2008; 36 (11): 3781-90. PMID: 18492718

3. Burger RM, Projan SJ, Horwitz SB, Peisach J. The DNA cleavage mechanism of iron-bleomycin. Kinetic resolution of strand scission from base propenal release. J Biol Chem. 1986; 261 (34): 15955-9. PMID: 2430964

4. Tounekti O, Pron G, Belehradek J, Jr., Mir LM. Bleomycin, an apoptosis-mimetic drug that induces two types of cell death depending on the number of molecules internalized. Cancer Res. 1993; 53 (22): 5462-9. PMID: 7693342

5. Kasper M, Barth $\mathrm{K}$. Bleomycin and its role in inducing apoptosis and senescence in lung cells - modulating effects of caveolin-1. Curr Cancer Drug Targets. 2009; 9 (3): 341-53. PMID: 19442053

6. Gelinas R, Chesler EJ, Vasconcelos D, Miller DR, Yuan Y, Wang K, et al. A genetic approach to the prediction of drug side effects: bleomycin induces concordant phenotypes in mice of the collaborative cross. Pharmgenomics Pers Med. 2011; 4: 35-45. PMID: 23226052

7. Hay J, Shahzeidi S, Laurent G. Mechanisms of bleomycininduced lung damage. Arch Toxicol. 1991; 65 (2): 81-94. PMID: 1711838

8. Hemmatia A, Aghelb $\mathrm{N}$, Nazari $\mathrm{Z}$, Mohammadian $\mathrm{B}$, Hasanvanda N. Protective effect of grape seed extract against the fibrogenic effect of bleomycin in rat lung. Iran J Pharmaceutical $\begin{array}{llll}\text { Sci. } & 2006 ; & 2 & \text { (3): }\end{array}$ 
9. Yang F, Oz HS, Barve S, de Villiers WJ, McClain CJ, Varilek GW. The green tea polyphenol (-)-epigallocatechin-3-gallate blocks nuclear factor-kappa B activation by inhibiting I kappa B kinase activity in the intestinal epithelial cell line IEC-6. Mol Pharmacol. 2001; 60 (3): 528-33. PMID: 11502884

10. Yang GY, Liao J, Kim K, Yurkow EJ, Yang CS. Inhibition of growth and induction of apoptosis in human cancer cell lines by tea polyphenols. Carcinogenesis. 1998; 19 (4): 611-6. PMID: 9600345

11. Chung FL. The prevention of lung cancer induced by a tobacco-specific carcinogen in rodents by green and black Tea Proc Soc Exp Biol Med. 1999; 220 (4): 244-8. PMID: 10202397

12. Silverberg JI, Jagdeo J, Patel M, Siegel D, Brody N. Green tea extract protects human skin fibroblasts from reactive oxygen species induced necrosis. J Drugs Dermatol. 2011; 10 (10): 1096101. PMID: 21968658

13. Yuan JM, Sun C, Butler LM. Tea and cancer prevention: epidemiological studies. Pharmacol Res. 2011; 64 (2): 123-35. PMID: 21419224

14. Katiyar SK, Agarwal R, Zaim MT, Mukhtar H. Protection against N-nitrosodiethylamine and benzo[a]pyrene-induced forestomach and lung tumorigenesis in $\mathrm{A} / \mathrm{J}$ mice by green tea. Carcinogenesis. 1993; 14 (5): 849-55. PMID: 8504476

15. Baek SJ, Kim JS, Jackson FR, Eling TE, McEntee MF, Lee $\mathrm{SH}$. Epicatechin gallate-induced expression of NAG-1 is associated with growth inhibition and apoptosis in colon cancer cells. Carcinogenesis. 2004; 25 (12): 2425-32. PMID: 15308587

16. Fujiki H, Suganuma M. Green tea: an effective synergist with anticancer drugs for tertiary cancer prevention. Cancer Lett. 2012 28; 324 (2): 119-25. PMID: 22626556

17. Spinella F, Rosano L, Decandia S, Di Castro V, Albini A, Elia $\mathrm{G}$, et al. Antitumor effect of green tea polyphenol epigallocatechin3-gallate in ovarian carcinoma cells: evidence for the endothelin-1 as a potential target. Exp Biol Med (Maywood). 2006; 231 (6): 1123-7. PMID: 16741061

18. Zhu BH, Zhan WH, Li ZR, Wang Z, He YL, Peng JS, et al. (-)Epigallocatechin-3-gallate inhibits growth of gastric cancer by reducing VEGF production and angiogenesis. World $\mathrm{J}$ Gastroenterol. 2007; 13 (8): 1162-9. PMID: 17451194

19. Kundu JK, Na HK, Chun KS, Kim YK, Lee SJ, Lee SS, et al. Inhibition of phorbol ester-induced COX-2 expression by epigallocatechin gallate in mouse skin and cultured human mammary epithelial cells. J Nutr. 2003; 133 (11 Suppl 1): 3805S10S. PMID: 146088118

20. Amin AR, Khuri FR, Chen ZG, Shin DM. Synergistic growth inhibition of squamous cell carcinoma of the head and neck by erlotinib and epigallocatechin-3-gallate: the role of p53-dependent inhibition of nuclear factor-kappaB. Cancer Prev Res (Phila). 2009; 2 (6): 538-45.PMID: 19470788
21. Ravindranath MH, Saravanan TS, Monteclaro CC, Presser N, Ye X, Selvan SR, et al. Epicatechins Purified from Green Tea (Camellia sinensis) Differentially Suppress Growth of GenderDependent Human Cancer Cell Lines. Evid Based Complement Alternat Med. 2006; 3 (2): 237-47. PMID: 16786054

22. Singh M, Bhui K, Singh R, Shukla Y. Tea polyphenols enhance cisplatin chemosensitivity in cervical cancer cells via induction of apoptosis. Life Sci. 2013; 19; 93 (1): 7-16. PMID: 23399702

23. Ashrafi SA, Hosseinimehr SJ, Varmira K, Abedi SM. Radioimmunotherapy with (131) i-bevacizumab as a specific molecule for cells with overexpression of the vascular endothelial growth factor. Cancer Biother Radiopharm. 2012; 27 (7): 420-5. PMID: 22690909

24. Sharma H, Sen S, Singh N. Molecular pathways in the chemosensitization of cisplatin by quercetin in human head and neck cancer. Cancer Biol Ther. 2005; 4 (9): 949-55. PMID: 160822193

25. Kang KS, Kang BC, Lee BJ, Che JH, Li GX, Trosko JE, et al. Preventive effect of epicatechin and ginsenoside $\mathrm{Rb}(2)$ on the inhibition of gap junctional intercellular communication by TPA and $\mathrm{H}(2) \mathrm{O}(2)$. Cancer Lett. 2000; 152 (1): 97-106. PMID: 10754211

26. Schlachterman A, Valle F, Wall K, Azios N, Castillo L, Morell $\mathrm{L}$, et al. Combined resveratrol, quercetin, and catechin treatment reduces breast tumor growth in a nude mouse model. Transl Oncol. 2008; 1 (1): 19-27. PMID: 18607509

27. Horie N, Hirabayashi N, Takahashi Y, Miyauchi Y, Taguchi H, Takeishi K. Synergistic effect of green tea catechins on cell growth and apoptosis induction in gastric carcinoma cells. Biol Pharm Bull. 2005; 28 (4): 574-9. PMID: 15802789

28. Zhang G, Miura Y, Yagasaki K. Induction of apoptosis and cell cycle arrest in cancer cells by in vivo metabolites of teas. Nutr Cancer. 2000; 38 (2): 265-73. PMID: 11525605

29. Mackenzie GG, Oteiza PI. Modulation of transcription factor NF-kappaB in Hodgkin's lymphoma cell lines: effect of (-)epicatechin. Free Radic Res. 2006; 40 (10): 1086-94. PMID: 17015253

30. Kim D, Mollah ML, Kim K. Induction of apoptosis of SW480 human colon cancer cells by (-)-epicatechin isolated from Bulnesia sarmienti. Anticancer Res. 2012; 32 (12): 5353-61. PMID: 23225437

31. Saha A, Kuzuhara T, Echigo N, Suganuma M, Fujiki H. New role of (-)-epicatechin in enhancing the induction of growth inhibition and apoptosis in human lung cancer cells by curcumin. Cancer Prev Res (Phila). 2010; 3 (8): 953-62. PMID: 20606042 